\title{
The Role of Glial Cell Line-Derived Neurfotrophic Factor in the Functioning of the Nervous System (Review)
}

\author{
DOI: $10.17691 /$ stm2015.7.4.27
}

Received August 13, 2015

T.V. Shishkina, PhD Student, Neurotechnology Department, Institute of Biology and Biomedicine ${ }^{1:}$

Laboratory Technician, Molecular and Cell Technologies Department, Central Research Laboratory2; M.V. Vedunova, DSc, Head of the Laboratory for Neuroprotection Methods Development, Institute of Biology and Biomedicine ${ }^{1}$; Senior Researcher, Biochemistry Department, Central Research Laboratory2; T.A. Mishchenko, PhD, Junior Researcher, Molecular and Cell Technologies Department, Central Research Laboratory2: Junior Researcher, Laboratory for Pharmacological Properties of Neurotropic Drugs Research, Institute of Biology and Biomedicine';

I.V. Mukhina, DSc, Professor, Head of the Central Research Laboratory2; Head of the Department Normal Physiology named after N.Y. Belenkov2; Professor, Neurotechnology Department, Institute of Biology and Biomedicine ${ }^{1}$; Leading Researcher, Group of Tissues Cryopreservation and Biotechnology ${ }^{3}$

${ }^{1}$ Lobachevsky State University of Nizhni Novgorod, 23 Prospekt Gagarina, Nizhny Novgorod, 603950,

Russian Federation;

${ }^{2}$ Nizhny Novgorod State Medical Academy, 10/1 Minin and Pozharsky Square, Nizhny Novgorod, 603005,

Russian Federation;

${ }^{3}$ Privolzhsky Federal Research Medical Center, Ministry of Health of the Russian Federation,

18 Verkhne-Volzhskaya naberezhnaya St., Nizhny Novgorod, 603155, Russian Federation

Glial cell line-derived neurotrophic factor (GDNF) is one of the most important factors participating in the neuronal survival as well as promoting the differentiation and maintenance of various cellular populations in the central and peripheral nervous systems. In contrast to other neurotrophic factors, GDNF does not directly bind to its receptor. For the implementation of GDNF biological functions, the presence of coreceptor, acting as a mediator in the interaction with the receptor, is necessary required. Receptor with tyrosine kinase activity (Ret) regarded as the main receptor to GDNF, able to subsequent launch an intracellular molecular cascade.

Particular attention to GDNF investigation caused by the fact that, among other neurotrophic factors GDNF has potent neuroprotective effect. Therefore, GDNF is considered as a possible factor for the correction of various nervous system disorders, including neurodegenerative diseases.

In this review basic information concerning the molecular structure of GDNF and its receptors as well as the mechanisms for implementation the main functions of GDNF from the beginning of active receptor complex formation to the subsequent launching of intracellular signaling cascades until appropriate cellular response achieving, is collected. Furthermore, the review contains the data, indicating the possible GDNF effect on synaptogenesis.

Key words: glial cell line-derived neurotrophic factor; GDNF; co-receptors; GFR $\alpha$; receptor with tyrosine kinase activity Ret.

Neurotrophic factors are polypeptides which regulate the development, maintenance, functioning and plasticity of vertebrate central nervous system. Although they were initially identified as factors involved in the neuronal survival, they also control many other processes, from cell proliferation, the differentiation of axons, the growth of dendrites and synaptic transmission modulation to the functional neural networks activity $[1,2]$.

The effects of neurotrophic factors lie in their modulation of biological processes at different levels. Generally, this influence is concerned with the regulation of gene expression, controlling the production of functionally significant proteins, receptors and neurotransmitters, and with respective switching on and/ or off the alternative regulatory systems [3-5].

One of the endogenic neurotrophic factors regarded as a powerful therapeutic agent is glial cell line-derived neurotrophic factor (GDNF). Its main action is connected with the influence on the central nervous system, however its additional functions and effects on other tissues, are also described [6-8].

GDNF is a necessary factor for normal brain development in the embryogenesis as it contributes to the survival and differentiation of different populations of neurons. GDNF plays a significant neuroprotective role in neurodegenerative diseases and in other pathologies of the central nervous system. Many studies have shown its therapeutic action in Parkinson's disease and during ischemic processes. However, a question concerning the mechanisms of GDNF effects implementation remains unclear and further investigation of these issues is required [9-12].

For contacts: Vedunova Mariya Valerievna, e-mail: MVedunova@yandex.ru 


\section{The structure of glial cell line-derived neurotrophic factor}

Glial cell line-derived neurotrophic factor was first purified from glial cells in 1993 and was identified as a survival factor for the embryonic dopaminergic neurons in vitro. Afterwards it became clear that GDNF also acts as a powerful neurotrophic factor for other types of neurons in the central and peripheral nervous systems in vivo $[13,14]$.

GDNF is a protein molecule which contains a cysteine "knot" and characterizing by two long signal sequences formed by pairs of anti-parallel $\beta$-strands [15]. To form a dimer, monomers are bound in a "headtail" arrangement. Due to the anti-parallel orientation, GDNF has a left-right symmetry indicating that the structure of this neurotrophin contains a symmetrical binding site for a dimerized receptor. A structural and functional analysis has shown the first 39 amino acids at the N-terminal of GDNF are not required for its biological activity. Moreover, 3D structures at the N-terminal are not detected. The C-terminal is crucial for GDNF stability and for its biological activity: at the C-terminal there is a $\beta$-spiral signal sequence that takes part in GDNF binding with GFR $\alpha 1$-receptor [16-18].

An immature GDNF molecule contains 211 amino acids, and includes signal sequence cleavage sites and a pro-domain. Mature molecules have a molecular mass of $35 \mathrm{kDa}$ and exist in 134 amino acids. During maturation, the protein is glycosylated and a homodimer is formed through covalent disulfide bonds [13]. Only in the form of the glycosylated homodimer, GDNF is able to implement its different biological functions. GDNF is initially synthesized in the form of pro-neurotrophin pro-GDNF.

Two forms of the immature peptide obtained by alternative splicing of mRNA were detected: (a)proGDNF, and (b)pro-GDNF. (b)pro-GDNF can induce the $\mathrm{Ca}^{2+}$-dependent depolarization in neurons [19]. It was discovered that the isoform (a)pro-GDNF is localized in the Golgi apparatus, while the (b)pro-GDNF is associated with the secretory fraction. The roles of different GDNF isoforms are not currently identified. The human brain has additional protein isoforms, one of them being typical of patients with Alzheimer's disease [20].

The GDNF gene is located on 5p12-P13.1 chromosome. It consists of two exons, one of them encodes the mature GDNF protein as well as the cleavage site used for pro-GDNF formation [21, 22].

The GDNF family contains four members: glial cell line-derived neurotrophic factor, neurturin, artemin and persephin. They all play important role in the maintaining of viability, proliferation, differentiation and migration of neuron populations [23].

Neurturin (NRTN) is approximately $42 \%$ homologous to the sequence of mature GDNF. It was demonstrated that NRTN influences on the dopaminergic neurons survival in vitro and in vivo [24-26]. Despite the homology and the ability for binding with the same group of receptors, the biological NRTN effects are different from the GDNFmediated effects.

Persephin (PSPN) is approximately $40 \%$ identical to GDNF and NRTN. Like all other members of GDNF family it helps to maintain the vital activity of many neuron types, including the brain dopaminergic neurons, motor neurons and the forebrain basal cholinergic neurons [27-31].

Artemin (ARTN) is the most distant member of GDNF family, being only $36 \%$ homologous to GDNF. It was shown artemin contributes to the survival and maintenance of sensory and sympathetic neurons in vitro. It able to prevent neuropathic pain and morphological and neurochemical changes in animals' brains. However, the expression of this GDNF family member is limited to the embryonic period [32-37].

\section{GDNF receptors}

GDNF signaling cascades is mediated by binding with a membrane-bound receptor consisting of 2 units. One of them, GFR $\alpha$, is a ligand-binding component, specific for the GDNF family ligand co-receptor, the other is a receptor with tyrosine kinase activity Ret. Together they form a functional unit of the receptors for binding with GDNF [38-40].

The GFR $\alpha$ co-receptors family includes four representatives (GFR $\alpha$ 1-4), which determine the specificity of the ligand and act as supplementary co-receptors for GDNF [41]. GFR $\alpha$ structure has no intracellular domain, therefore this receptor performs the role of a signal transmitter to other proteins, in particular to Ret - a receptor with tyrosine kinase activity, which in turn activates several intracellular signaling cascades [23, 42, 43].

GDNF acts not only at the site of its synthesis, but also remotely. It was found that neurons are capable of GDNF endocytosis. Absorbed by the cells bodies and the proximal dendrites using the retrograde transport system, GDNF is transferred to the cell body and to the afferent synapses [44-47].

Each ligand of the GDNF family has preferred co-receptors GFR $\alpha$ : GFR $\alpha 1$ - for GDNF [38, 39], GFR $\alpha 2$ - for neurturin [48-51], GFR $\alpha 3$ - for artemin $[32,52,53]$ and GFR $\alpha 4$ - for persephin $[54,55]$.

The structure of the GFR $\alpha 1$ receptor includes three domains (D1, D2 and D3) that are common to all mammals. GFR 1 (molecular weight about $47 \mathrm{kDa}$ ) consists of 468 amino acids, and has three potential $\mathrm{N}$-binding sites for glycosylation. It was shown that this protein is bound to the cellular surface by the GPI-anchor (glycosylphosphatidylinositol anchor). GFR $\alpha 1$ can also be an alternative receptor for neurturin for Ret activation. However, NRTN-GFR $\alpha 1$ binding is much weaker than with GFR $\alpha 2$ [38, 56-58]. 


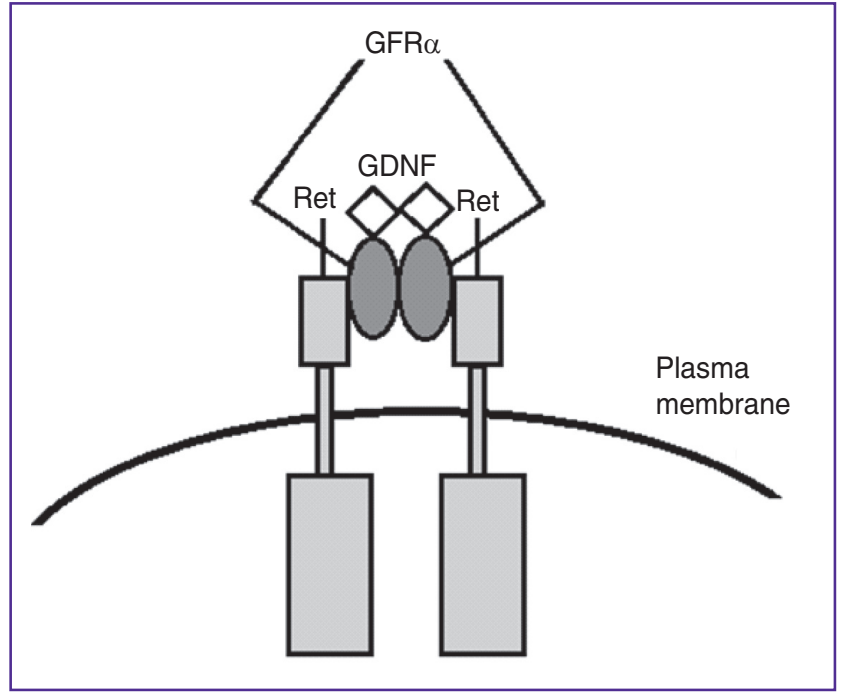

Figure 1. GDNF signaling activation via Ret. GDNF: glial cell line-derived neurotrophic factor; GFR $\alpha$ : specific co-receptor for GDNF; Ret: receptor with tyrosine kinase activity

In 1997 the alternative GFR $\alpha 1$ isoforms - GFR $\alpha 1 a$ and GFR $\alpha 1 \mathrm{~b}$, resulting in alternative splicing, were determined [51, 59, 60]. GFR $\alpha 1 a$ is expressed in all parts of the nervous system, while GFR $\alpha 1 \mathrm{~b}$ was found in the peripheral tissues [53, 59-61].

For further signal transmission the GDNF/GFR $\alpha$ complex binds with Ret, acting as a common signal receptor for ligands of glial cell line-derived neurotrophic factors family (GFLs) (Figure 1) [42, 56, 62, 63].

The gene, encoding the receptor with tyrosine kinase activity, is a proto-oncogene which was discovered in 1985. It has been noted its participation in the activation of DNA reconstruction [64].

Ret is a transmembrane protein; in its extracellular part there are four repeated cadherin-like calciumbinding sites and a cysteine-enriched domain. The difference between Ret extracellular region and the other tyrosine kinase receptors is the lack of leucine repeats, the immunoglobulin and the fibronectin-like domains which are common to many other similar receptors [65-67]. The intracellular part is a typical tyrosine kinase domain, consisting of two parts. The tyrosine kinase domain mediates autophosphorylation after the receptor activation. Based on its homology with cadherin, the cadherin-like domains can mediate cellular adhesion, though their functions are not currently well-defined [68]. The calcium-binding site, located between the second and third cadherin-like domains, is required for folding, secretion and signal transmission [69-72]. The cysteineenriched domain exists in 16 cysteine residues and plays a binding role with the co-receptor GFR $\alpha$ [73].

The key Ret functions are performed by the intracellular kinase domain. Ligand-induced Ret-dimerization of two closely located catalytic domains causes mutual transphosphorylation and the further signal transmission to intracellular proteins [74-76].

Ret-mediated GDNF signaling includes two main signal cascades which are contributed to cell survival in a variety of neuronal and non-neuronal populations: the Ras/ERK (MAPK), and PI3K/Akt pathways (Figure 2).

An evolutionarily earlier signaling cascade - mitogenactivated protein kinase (MAPK) - plays a fundamental role in the regulation of different cellular processes, including embryogenesis, proliferation, the cellular growth, differentiation and survival, based on the signals obtained from the cellular surface as well as those reflecting the cellular metabolic state [77-79].

Launching of MAPK cascade by GDNF/GFR $\alpha /$ RET complex leads to the activation of several transcription factors (including c-fos and c-myc, p53, SMAD1-4, Sap1a, SP1 and Elk-1), which are participated in the control of cellular mobility, proliferation, differentiation and survival [77, 80, 81]. The known effect of increasing the survival is carry out due to phosphorylation and RSK (p90 ribosomal S6 kinase) activation, in turn phosphorylating the transcription factor CREB, causing the "survival" genes activation $[82,83]$.

Phosphoinositol-3-kinase (PI3K) is the main viability regulator of variety cellular populations [84]. There are two main routes to PI3K activation: 1) PI3K can be directly activated by GTP-bound Ras, or 2) activation with the Grb2/GAB1/2-complex formation. The PI3K/ Akt signal pathway can suppress the caspase- 3 and -9 action, the apoptotic protein, BAD, and can activate the "survival" genes (Bcl-2 and IAPS), as well as causing the transcription factors phosphorylation, suppressing their ability to activate the apoptotic genes $[85,86]$.

GFR $\alpha$ expression in lacking Ret regions, and the capacity of GDNF for activating signal mechanisms in constant cell lines and primary neural cultures with low Ret expression, indicates the presence of Ret-independent pathway for GDNF/GFR $\alpha 1$ signal transmission. The neural cell adhesion molecule (NCAM) was identified as a new GDNF-receptor in neurons [87]. Subsequently it was found that NCAM is also a supplementary receptor for at least two members of GDNF family ligands NRTN and ARTN [88].

NCAM - molecules of non-cadherin adhesion system, are transmembrane proteins once crossing the plasma membrane. The intracellular domains take part in the cellular signal transmission. The major intracellular part of NCAM polypeptide chain is folded into five immunoglobulin-like domains and also includes one or two domains that are similar to repeats occurring in fibronectin molecules [89, 90].

GFR $\alpha 1$ - NCAM binding leads to the formation a highaffinity receptor to GDNF, with further activation of the cytoplasmic Src-like kinase, Fyn, and the focal adhesion kinase, FAK. The presence of GDNF contributes to cell adhesion via Fyn and FAK, while the GDNF lacking causes GFR $\alpha 1$ inhibition of NCAM-mediated cellular 


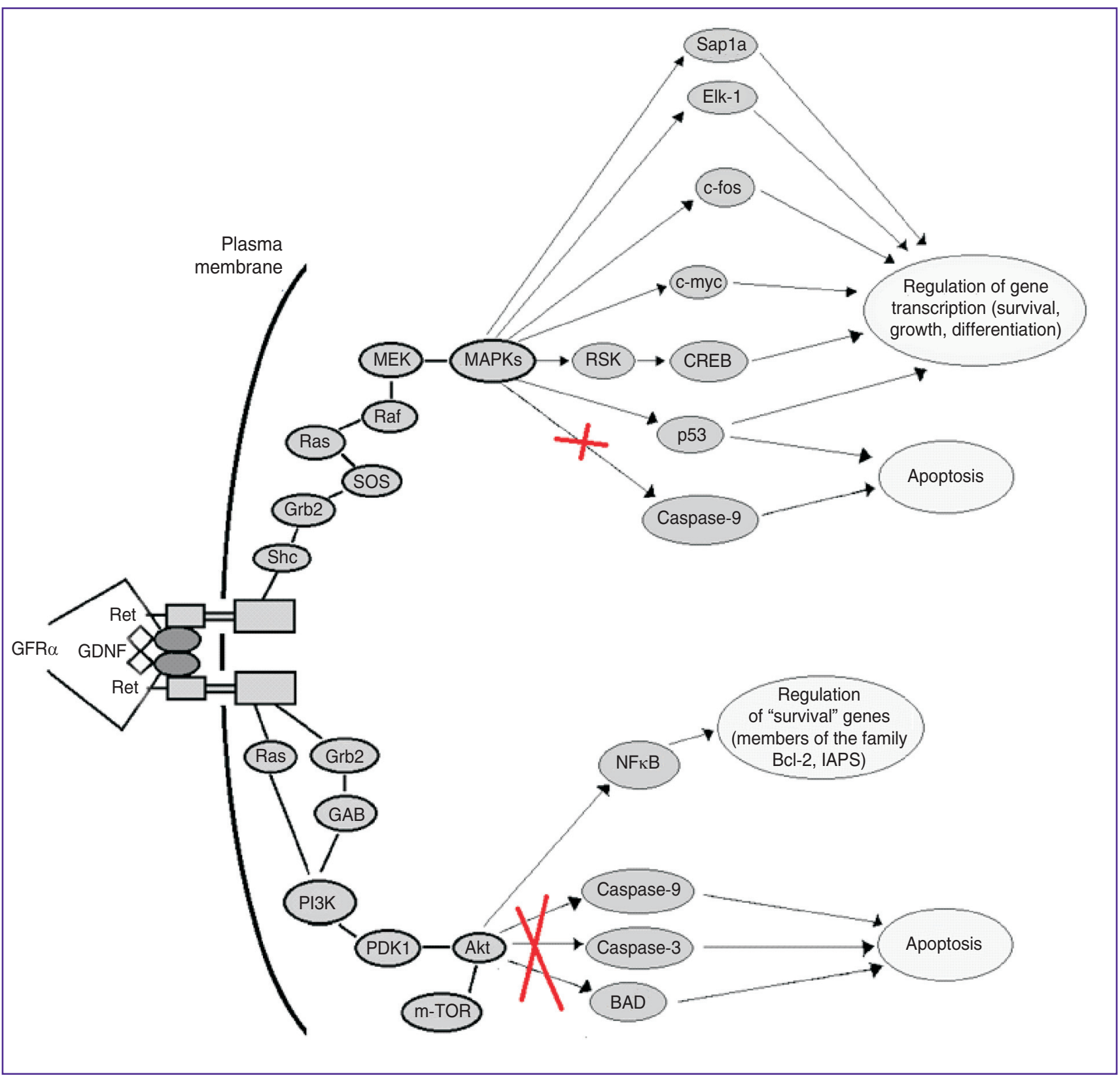

Figure 2. Schematic representation of GDNF signaling pathways through the GFR $\alpha$ Ret-receptor complex. Akt: protein kinase B; BAD: pro-apoptotic protein; c-fos: protein-regulator of transcription of a number of inducible genes; c-myc: gene, encoding protein transcription factor; CREB: CAMP-dependent transcription factor; Elk-1: ETS-domain-containing protein, activator of transcription; GAB: adaptor protein, activator of PI3K; GDNF: glial cell line-derived neurotrophic factor; GFR $\alpha$ : specific co-receptor for GDNF; Grb2: adaptor protein; m-TOR: protein kinase with serine-threonine specificity; MAPK: mitogen-activated protein kinase; MEK: kinase of MAPK; NFкB: transcription nuclear factor kappa B; p53: transcription factor regulating the cellular cycle; PDK1: phosphoinositidedependent protein kinase; PI3K: phosphoinositol-3-kinase; Raf: serine-threonine protein kinase; Ras: small GTF-binding protein; Ret: receptor with tyrosine kinase activity; RSK: p90 kinase of ribosomal protein S6; Sap1a: transcription factor; Shc: adaptor protein; SOS: guanine nucleotides exchange factor

adhesion [87, 91]. GDNF binding with NCAM stimulates the Schwann cells migration, the growth of axons in the hippocampus and cortical neurons without depending on the presence of a receptor with tyrosine kinase activity $[92,93]$.

\section{GDNF influence on synaptogenesis}

According to modern views, the minimal functional unit of the nervous system is a neural network. Thus the processes of memory consolidation, transmission 
and storage of information take place at the level of neuron networks [94-96]. Each neuron that is a part of a network is continuously participating in the transmission of information. The overall signal obtained from the neurons, causes a change in their membrane potential and the generation of an action potential which in turn is transmitted to other neurons involved in this functional ensemble. The data concerning the role of certain signal molecules (especially GDNF) in the functioning of the whole network is of special interest.

Some representatives of GFLs family take part not only in the development of synapses, but also in synaptic plasticity. It was shown that GDNF able to stimulate the release of neurotransmitter in midbrain dopaminergic neurons and in neuromuscular synapses, and thus, regulates the formation and functional properties of the synaptic endings. An increase in the number of clusters of presynaptic vesicles observed in midbrain dopaminergic neurons reveals the role of GDNF in presynaptic differentiation [97, 98]. Interestingly, GDNF modulates the A-type of $\mathrm{K}^{+}$channels and, thus, neuronal excitability in vitro [99]. It was also revealed that chronic GFLs application induces a considerable increase in the number and size of presynaptic vesicles and the clusters of acetylcholine receptor (AchR), indicating that GFLs family members are able to coordinate the development of neuromuscular synapses via pre- and post-synaptic mechanisms [100]. Moreover, in dopaminergic neurons cultures GDNF causes rapid and reversible excitability of neurons. This effect supposed to be caused by $\mathrm{K}^{+}$ channels suppression, involving in the mechanisms that switch on MAPK activation. GDNF also leads to an increase in the permeability of $\mathrm{Ca}^{+}$channels. Changes in excitability of neurons and ion channels result in functional modulation of synaptic transmission. Thus, GDNF able to consider as a substance that actively affects on the pattern of neural networks functional activity [101, 102].

Investigation the role of GDNF and its main receptor in the stabilization of synaptic contacts at the early stages of synaptogenesis is of special interest. According to the expression time studies, and the localization of GDNF and its receptor in the developing hippocampus, GDNF and GFR $\alpha 1$ are ligand-induced molecules for cellular adhesion [103]. An immobilized source of exogenic GFR $\alpha 1$, by imitating postsynaptic localization, can induce differentiation of the hippocampal neurons. Similar effects were obtained for excitatory and inhibitory hippocampal neurons [103]. However, the issue of whether this mechanism is typical to all neuronal populations remains open. It was shown that GDNFinduced the development of presynaptic terminals does not depend on Ret-mediated intracellular mechanisms, but is partially depends on NCAM. Therefore, additional effector molecule reactions are likely to take part in the development $[104,105]$. The capacity of GDNF to cause transhomophylic interactions between GFR $\alpha 1$ molecules regarded as one of the mechanisms of synaptogenesis. This mechanism is connected with soluble and membrane-bound molecules actions [106].

The studies revealed that the neurotrophic factors GDNF and BDNF can stimulate promotor activity of GluR2 subunits of AMPA receptors, playing a significant role in synaptogenesis and the formation of neural networks, as well as in synaptic plasticity, including longterm potentiation (LTP) and long-term depression (LTD) $[107,108,109]$, through neuron suppressing element (NRSE) [110].

\section{Conclusion}

GDNF plays a key role in neurogenesis and also is a necessary factor for maintaining the viability and functioning of neurons. The GDNF protective action connected with ability to inhibit apoptosis, triggering the signal cascades that affect on gene expression. GDNF implements the neurotrophic activity through the formation of an active complex with its receptors GDNF/GFR $\alpha /$ Ret. This complex activates the MAPK and PI3K signaling pathways which leads to the transcription factors activation and to the suppression of pro-apoptotic proteins and caspases.

Despite this, the physiological mechanisms of GDNF action and the whole spectrum of its neuroprotective potential have not been fully discovered. Study of all aspects of GDNF influence on neural brain networks adaptation to stress-conditions, as well as on the solution to the problem of protein penetration through the hematoencephalic barrier could stimulate the development of new therapeutic strategies and the creation of medicines based on this neurotrophic factor application.

Study Funding. The work was supported by the Ministry of Education and Science of the Russian Federation under the Federal Grant Program "Studies and Developments in priority directions of the scientifictechnical complex of Russia for 2014-2020". Grant agreement No.14.578.21.0094 dated 24.11.2014 (the unique identifying number of the project is RFMEFI57814X0094).

Conflicts of Interest. The authors have no conflicts of interest.

\section{References}

1. Chao M.V. Neurotrophins and their receptors: a convergence point for many signalling pathways. Nat Rev Neurosci 2003; 4(4): 299-309, http://dx.doi.org/10.1038/nrn1078.

2. Davies A.M. Regulation of neuronal survival and death by extracellular signals during development. EMBO J 2003; 22(11): 2537-2545, http://dx.doi.org/10.1093/emboj/cdg254.

3. Gomazkov O.A. Neyrotroficheskie faktory mozga: spravochno-informatsionnoe izdanie. CD-versiya [Brain-derived neurotrophic factor: the reference edition. CD-version]. Moscow; 2004.

4. Sakharnova T.A., Vedunova M.V., Mukhina I.V. Brain- 
derived neurotrophic factor (BDNF) and its role in the functioning of the central nervous system. Neurochemical Journal 2012; 6(4): 251-259, http://dx.doi.org/10.1134/s1819712412030129.

5. Vedunova M.V., Mishchenko T.A., Mitroshina E.V., Mukhina I.V. TrkB-mediated neuroprotective and antihypoxic properties of brain-derived neurotrophic factor. Oxid Med Cell Longev 2015; 2015: 453901, http://dx.doi.org/10.1155/2015/ 453901 .

6. Costantini F., Shakya R. GDNF/Ret signaling and the development of the kidney. Bioessays 2006; 28(2): 117-127, http://dx.doi.org/10.1002/bies.20357.

7. Naughton C.K., Jain S., Strickland A.M., Gupta A., Milbrandt J. Glial cell-line derived neurotrophic factor-mediated RET signaling regulates spermatogonial stem cell fate. Biol Reprod 2006; 74(2): 314-321, http://dx.doi.org/10.1095/ biolreprod.105.047365.

8. Mironov V.I., Romanov A.S., Simonov A.Y., Vedunova M.V., Kazantsev V.B. Oscillations in a neurite growth model with extracellular feedback. Neurosci Lett 2014; 570: 1620, http://dx.doi.org/10.1016/j.neulet.2014.03.041.

9. Mickiewicz A.L., Kordower J.H. GDNF family ligands: a potential future for Parkinson's disease therapy. CNS Neurol Disord Drug Targets 2011; 10(6): 703-711, http://dx.doi.org/10.21 74/187152711797247876.

10. Duarte E.P., Curcio M., Canzoniero L.M., Duarte C.B. Neuroprotection by GDNF in the ischemic brain. Growth Factors 2012; 30(4): 242-257, http://dx.doi.org/10.3109/08977194.2012.6 91478.

11. Allen S.J., Watson J.J., Shoemark D.K., Barua N.U., Patel N.K. GDNF, NGF and BDNF as therapeutic options for neurodegeneration. Pharmacol Ther 2013; 138(2): 155-175, http://dx.doi.org/10.1016/j.pharmthera.2013.01.004.

12. Vedunova M.V., Sakharnova T.A., Mitroshina E.V., Shishkina T.V., Astrakhanova T.A., Mukhina I.V. Antihypoxic and neuroprotective properties of BDNF and GDNF in vitro and in vivo under hypoxic conditions. Sovremennye tehnologii $v$ medicine 2014; 6(4): 38-47.

13. Lin L.F., Doherty D.H., Lile J.D., Bektesh S., Collins F. GDNF: a glial cell line-derived neurotrophic factor for midbrain dopaminergic neurons. Science 1993; 260(5111): 1130-1132, http://dx.doi.org/10.1126/science.8493557.

14. He Z., Jiang J., Kokkinaki M., Golestaneh N., Hofmann M.C., Dym M. GDNF upregulates c-Fos transcription via the Ras/Erk1/2 pathway to promote mouse spermatogonial stem cell proliferation. Stem Cells 2008; 26(1): 266-278, http://dx.doi. org/10.1634/stemcells.2007-0436.

15. Eigenbrot C., Gerber N. X-ray structure of glial cellderived neurotrophic factor at $1.9 \mathrm{~A}$ resolution and implications for receptor binding. Nat Struct Biol 1997; 4(6): 435-438, http://dx.doi. org/10.1038/nsb0697-435.

16. Chen Z.Y., He Z.Y., He C., Lu C.L., Wu X.F. Human glial cell-line-derived neurotrophic factor: a structure-function analysis. Biochem Biophys Res Commun 2000; 268(3): 692-696, http:// dx.doi.org/10.1006/bbrc.2000.2196.

17. Chen Z., He Z., He C., Lu C., Wu X. A structure-function analysis of human GDNF. Acta Biochimica et Biophysica Sinica 2000; 32(3): 243-247.

18. Parkash V., Lindholm P., Peränen J., Kalkkinen N., Oksanen E., Saarma M., Leppänen V.M., Goldman A. The structure of the conserved neurotrophic factors MANF and CDNF explains why they are bifunctional. Protein Eng Des Sel 2009; 22(4): 233-241, http://dx.doi.org/10.1093/protein/gzn080.

19. Lonka-Nevalaita L., Lume M., Leppänen S., Jokitalo E., Peränen J., Saarma M. Characterization of the intracellular localization, processing, and secretion of two glial cell line-derived neurotrophic factor splice isoforms. J Neurosci 2010; 30(34): 11403-11413, http://dx.doi.org/10.1523/JNEUROSCI.588809.2010 .

20. Airavaara M., Pletnikova O., Doyle M.E., Zhang Y.E., Troncoso J.C., Liu Q.R. Identification of novel GDNF isoforms and cis-antisense GDNFOS gene and their regulation in human middle temporal gyrus of Alzheimer disease. J Biol Chem 2011; 286(52): 45093-45102, http://dx.doi.org/10.1074/jbc.M111.310250.

21. Schindelhauer D., Schuffenhauer S., Gasser T., Steinkasserer A., Meitinger T. The gene coding for glial cell line derived neurotrophic factor (GDNF) maps to chromosome $5 \mathrm{p} 12$ p13.1. Genomics 1995; 28(3): 605-607, http://dx.doi.org/10.1006/ geno.1995.1202.

22. Woodbury D., Schaar D.G., Ramakrishnan L., Black I.B. Novel structure of the human GDNF gene. Brain Res 1998; 803(12): 95-104, http://dx.doi.org/10.1016/S0006-8993(98)00627-1.

23. Sariola $H$., Saarma $M$. Novel functions and signalling pathways for GDNF. J Cell Sci 2003; 116(Pt 19): 3855-3862, http://dx.doi.org/10.1242/jcs.00786.

24. Kotzbauer P.T., Lampe P.A., Heuckeroth R.O., Golden J.P., Creedon D.J., Johnson E.M. Jr., Milbrandt J. Neurturin, a relative of glial-cell-line-derived neurotrophic factor. Nature 1996; 384(6608): 467-470, http://dx.doi.org/10.1038/384467a0.

25. Horger B.A., Nishimura M.C., Armanini M.P., Wang L.S., Poulsen K.T., Rosenblad C., Kirik D., Moffat B., Simmons L., Johnson E. Jr., Milbrandt J., Rosenthal A., Bjorklund A., Vandlen R.A., Hynes M.A., Phillips H.S. Neurturin exerts potent actions on survival and function of midbrain dopaminergic neurons. J Neurosci 1998; 18(13): 4929-4937.

26. Zihlmann K.B., Ducray A.D., Schaller B., Huber A.W., Krebs S.H., Andres R.H., Seiler R.W., Meyer M., Widmer H.R. The GDNF family members neurturin, artemin and persephin promote the morphological differentiation of cultured ventral mesencephalic dopaminergic neurons. Brain Res Bull 2005; 68(1-2): 42-53, http://dx.doi.org/10.1016/j.brainresbull.2004.10.012.

27. Widenfalk J., Nosrat C., Tomac A., Westphal H., Hoffer B., Olson L. Neurturin and glial cell line-derived neurotrophic factor receptor-beta (GDNFR-beta), novel proteins related to GDNF and GDNFR-alpha with specific cellular patterns of expression suggesting roles in the developing and adult nervous system and in peripheral organs. J Neurosci 1997; 17(21): 8506-8519.

28. Luukko K., Saarma M., Thesleff I. Neurturin mRNA expression suggests roles in trigeminal innervation of the first branchial arch and in tooth formation. Dev Dyn 1998; 213(2): $\quad 207-219, \quad$ http://dx.doi.org/10.1002/(SICl)10970177(199810)213:2<207::AID-AJA6>3.0.CO;2-K.

29. Milbrandt J., de Sauvage F.J., Fahrner T.J., Baloh R.H., Leitner M.L., Tansey M.G., Lampe P.A., Heuckeroth R.O., Kotzbauer P.T., Simburger K.S., Golden J.P., Davies J.A., Vejsada R., Kato A.C., Hynes M., Sherman D., Nishimura M., Wang L.C., Vandlen R., Moffat B., Klein R.D., Poulsen K., Gray C., Garce A., Johnson E.M. Jr. Persephin, a novel neurotrophic factor related to GDNF and neurturin. Neuron 1998; 20(2): 245-253, http://dx.doi.org/10.1016/S0896-6273(00)80453-5.

30. Golden J.P., DeMaro J.A., Osborne P.A., Milbrandt J., Johnson E.M. Jr. Expression of neurturin, GDNF, and GDNF familyreceptor mRNA in the developing and mature mouse. Exp Neurol 1999; 158(2): 504-528, http://dx.doi.org/10.1006/exnr.1999.7127.

31. Golden J.P., Milbrandt J., Johnson E.M. Jr. Neurturin and persephin promote the survival of embryonic basal forebrain cholinergic neurons in vitro. Exp Neurol 2003; 184(1): 447-455, http://dx.doi.org/10.1016/j.expneurol.2003.07.999.

32. Baloh R.H., Tansey M.G., Lampe P.A., Fahrner T.J., Enomoto H., Simburger K.S., Leitner M.L., Araki T., Johnson E.M. Jr., Milbrandt J. Artemin, a novel member of the 
GDNF ligand family, supports peripheral and central neurons and signals through the GFRalpha3-RET receptor complex. Neuron 1998; 21(6): 1291-1302, http://dx.doi.org/10.1016/S08966273(00)80649-2.

33. Nishino J., Mochida K., Ohfuji Y., Shimazaki T., Meno C., Ohishi S., Matsuda Y., Fujii H., Saijoh Y., Hamada H. GFR alpha3, a component of the artemin receptor, is required for migration and survival of the superior cervical ganglion. Neuron 1999; 23(4): 725-736, http://dx.doi.org/10.1016/S0896-6273(01)80031-3.

34. Honma Y., Araki T., Gianino S., Bruce A., Heuckeroth R., Johnson E., Milbrandt J. Artemin is a vascular-derived neurotropic factor for developing sympathetic neurons. Neuron 2002; 35(2): 267-282, http://dx.doi.org/10.1016/S0896-6273(02)00774-2.

35. Gardell L.R., Wang R., Ehrenfels C., Ossipov M.H., Rossomando A.J., Miller S., Buckley C., Cai A.K., Tse A., Foley S.F., Gong B., Walus L., Carmillo P., Worley D., Huang C., Engber T., Pepinsky B., Cate R.L., Vanderah T.W., Lai J., Sah D.W., Porreca F. Multiple actions of systemic artemin in experimental neuropathy. Nat Med 2003; 9(11): 1383-1389, http:// dx.doi.org/10.1038/nm944.

36. Bennett D.L., Boucher T.J., Michael G.J., Popat R.J., Malcangio M., Averill S.A., Poulsen K.T., Priestley J.V., Shelton D.L., McMahon S.B. Artemin has potent neurotrophic actions on injured C-fibres. J Peripher Nerv Syst 2006; 11(4): 330-345, http://dx.doi. org/10.1111/j.1529-8027.2006.00106.x.

37. Thornton P., Hatcher J.P., Robinson I., Sargent B., Franzén B., Martino G., Kitching L., Glover C.P., Anderson D., Forsmo-Bruce H., Low C.P., Cusdin F., Dosanjh B., Williams W., Steffen A.C., Thompson S., Eklund M., Lloyd C., Chessell I., Hughes J. Artemin-GFR $\alpha 3$ interactions partially contribute to acute inflammatory hypersensitivity. Neurosci Lett 2013; 545: 23-28, http://dx.doi.org/10.1016/j.neulet.2013.04.007.

38. Jing S., Wen D., Yu Y., Holst P.L., Luo Y., Fang M., Tamir R., Antonio L., Hu Z., Cupples R., Louis J.C., Hu S., Altrock B.W., Fox G.M. GDNF-induced activation of the ret protein tyrosine kinase is mediated by GDNFR-alpha, a novel receptor for GDNF. Cell 1996; 85(7): 1113-1124, http://dx.doi.org/10.1016/ S0092-8674(00)81311-2.

39. Treanor J.J., Goodman L., de Sauvage F., Stone D.M., Poulsen K.T., Beck C.D., Gray C., Armanini M.P., Pollock R.A., Hefti F., Phillips H.S., Goddard A., Moore M.W., Buj-Bello A., Davies A.M., Asai N., Takahashi M., Vandlen R., Henderson C.E., Rosenthal A. Characterization of a multicomponent receptor for GDNF. Nature 1996; 382(6586): 80-83, http://dx.doi.org/10.1038/ 382080a0.

40. Aron L. Genetic analysis of dopaminergic neuron survival GDNF/Ret signaling and the Parkinson's disease-associated gene DJ-1 [dissertation]. München: Ludwig-Maximilians-Universität München; 2009.

41. Serra M.P., Quartu M., Mascia F., Manca A., Boi M., Pisu M.G., Lai M.L., Del Fiacco M. Ret, GFRalpha-1, GFRalpha-2 and GFRalpha-3 receptors in the human hippocampus and fascia dentate. Int J Dev Neurosci 2005; 23: 425-438, http://dx.doi. org/10.1016/j.ijdevneu.2005.05.003.

42. Airaksinen M.S., Saarma M. The GDNF family: signalling, biological functions and therapeutic value. Nat Rev Neurosci 2002; 3(5): 383-394, http://dx.doi.org/10.1038/nrn812.

43. Lucini C., Facello B., Maruccio L., Langellotto F., Sordino P., Castaldo L. Distribution of glial cell line-derived neurotrophic factor receptor alpha-1 in the brain of adult zebrafish. $J$ Anat 2010; 217(2): 174-185, http://dx.doi.org/10.1111/j.14697580.2010.01254.x.

44. Tomac A., Widenfalk J., Lin L.F., Kohno T., Ebendal T., Hoffer B.J., Olson L. Retrograde axonal transport of glial cell line-derived neurotrophic factor in the adult nigrostriatal system suggests a trophic role in the adult. Proc Natl Acad Sci USA 1995; 92(18): 8274-8278, http://dx.doi.org/10.1073/pnas.92.18.8274.

45. Leitner M.L., Molliver D.C., Osborne P.A., Vejsada R., Golden J.P., Lampe P.A., Kato A.C., Milbrandt J., Johnson E.M. Jr. Analysis of the retrograde transport of glial cell line-derived neurotrophic factor (GDNF), neurturin, and persephin suggests that in vivo signaling for the GDNF family is GFRalpha coreceptor-specific. J Neurosci 1999; 19(21): 9322-9331.

46. Rind H.B., Butowt R., von Bartheld C.S. Synaptic targeting of retrogradely transported trophic factors in motoneurons: comparison of glial cell line-derived neurotrophic factor, brainderived neurotrophic factor, and cardiotrophin-1 with tetanus toxin. J Neurosci 2005; 25(3): 539-549, http://dx.doi.org/10.1523/ jneurosci.4322-04.2005.

47. Tsui C.C., Pierchala B.A. The differential axonal degradation of Ret accounts for cell-type-specific function of glial cell line-derived neurotrophic factor as a retrograde survival factor. J Neurosci 2010; 30: 5149-5158, http://dx.doi.org/10.1523/ JNEUROSCI.5246-09.2010.

48. Baloh R.H., Tansey M.G., Golden J.P., Creedon D.J., Heuckeroth R.O., Keck C.L., Zimonjic D.B., Popescu N.C., Johnson E.M. Jr., Milbrandt J. TrnR2, a novel receptor that mediates neurturin and GDNF signaling through Ret. Neuron 1997; 18(5): 793-802, http://dx.doi.org/10.1016/S0896-6273(00) 80318-9.

49. Buj-Bello A., Adu J., Piñón L.G., Horton A., Thompson J., Rosenthal A., Chinchetru M., Buchman V.L., Davies A.M. Neurturin responsiveness requires a GPI-linked receptor and the Ret receptor tyrosine kinase. Nature 1997; 387(6634): 721-724, http://dx.doi.org/10.1038/42729.

50. Klein R.D., Sherman D., Ho W.H., Stone D., Bennett G.L., Moffat B., Vandlen R., Simmons L., Gu Q., Hongo J.A., Devaux B., Poulsen K., Armanini M., Nozaki C., Asai N., Goddard A., Phillips H., Henderson C.E., Takahashi M., Rosenthal A. A GPI-linked protein that interacts with Ret to form a candidate neurturin receptor. Nature 1997; 387: 717-721, http://dx.doi.org/10.1038/42722.

51. Sanicola M., Hession C., Worley D., Carmillo P., Ehrenfels C., Walus L., Robinson S., Jaworski G., Wei H., Tizard R., Whitty A., Pepinsky R.B., Cate R.L. Glial cell line-derived neurotrophic factor-dependent RET activation can be mediated by two different cell-surface accessory proteins. Proc Natl Acad Sci USA 1997; 94(12): 6238-6243, http://dx.doi.org/10.1073/ pnas.94.12.6238.

52. Naveilhan P., Baudet C., Mikaels A., Shen L., Westphal H., Ernfors P. Expression and regulation of GFRalpha3, a glial cell line-derived neurotrophic factor family receptor. Proc Natl Acad Sci USA 1998; 95(3): 1295-1300, http://dx.doi.org/10.1073/ pnas.95.3.1295.

53. Widenfalk J., Tomac A., Lindqvist E., Hoffer B., Olson L. GFRalpha-3, a protein related to GFRalpha-1, is expressed in developing peripheral neurons and ensheathing cells. Eur J Neurosci 1998; 10(4): 1508-1517, http://dx.doi.org/10.1046/ j.1460-9568.1998.00192.x.

54. Enokido Y., de Sauvage F., Hongo J.A., Ninkina N., Rosenthal A., Buchman V.L., Davies A.M. GFRalpha-4 and the tyrosine kinase Ret form a functional receptor complex for persephin. Curr Biol 1998; 8(18): 1019-1022, http://dx.doi. org/10.1016/s0960-9822(07)00422-8.

55. Lindahl M., Poteryaev D., Yu L., Arumae U., Timmusk T., Bongarzone I., Aiello A., Pierotti M.A., Airaksinen M.S., Saarma M. Human glial cell line-derived neurotrophic factor receptor alpha 4 is the receptor for persephin and is predominantly expressed in normal and malignant thyroid medullary cells. J Biol Chem 2001; 276(12): 9344-9351, http://dx.doi.org/10.1074/jbc.m008279200.

56. Creedon D.J., Tansey M.G., Baloh R.H., Osborne P.A., 
Lampe P.A., Fahrner T.J., Heuckeroth R.O., Milbrandt J., Johnson E.M. Jr. Neurturin shares receptors and signal transduction pathways with glial cell line-derived neurotrophic factor in sympathetic neurons. Proc Natl Acad Sci USA 1997; 94(13): 7018-7023, http://dx.doi.org/10.1073/pnas.94.13.7018.

57. Suvanto P., Wartiovaara K., Lindahl M., Arumae U., Moshnyakov M., Horelli-Kuitunen N., Airaksinen M.S., Palotie A., Sariola H., Saarma M. Cloning, mRNA distribution and chromosomal localisation of the gene for glial cell line-derived neurotrophic factor receptor beta, a homologue to GDNFR-alpha. Hum Mol Genet 1997; 6(8): 1267-1273, http://dx.doi.org/10.1093/ $\mathrm{hmg} / 6.8 .1267$.

58. Airaksinen M.S., Titievsky A., Saarma M. GDNF family neurotrophic factor signaling: four masters, one servant? Mol Cell Neurosci 1999; 13(5): 313-325, http://dx.doi.org/10.1006/ mcne.1999.0754.

59. Dey B.K., Wong Y.W., Too H.P. Cloning of a novel murine isoform of the glial cell line-derived neurotrophic factor receptor. Neuroreport 1998; 9(1): 37-42, http://dx.doi. org/10.1097/00001756-199801050-00008.

60. Shefelbine S.E., Khorana S., Schultz P.N., Huang E., Thobe N., Hu Z.J., Fox G.M., Jing S., Cote G.J., Gagel R.F. Mutational analysis of the GDNF/RET-GDNFR alpha signaling complex in a kindred with vesicoureteral reflux. Hum Genet 1998; 102(4): 474-478, http://dx.doi.org/10.1007/s004390050724.

61. Yoong L.F., Peng Z.N., Wan G., Too H.P. Tissue expression of alternatively spliced GFRalpha1, NCAM and RET isoforms and the distinct functional consequence of ligand-induced activation of GFRalpha1 isoforms. Brain Res Mol Brain Res 2005; 139(1): 1-12, http://dx.doi.org/10.1016/j.molbrainres.2005.05.016.

62. Baloh R.H., Enomoto H., Johnson E.M. Jr., Milbrandt J. The GDNF family ligands and receptors - implications for neural development. Curr Opin Neurobiol 2000; 10(1): 103-110, http:// dx.doi.org/10.1016/s0959-4388(99)00048-3.

63. Wang $X$. Structural studies of GDNF family ligands with their receptors - Insights into ligand recognition and activation of receptor tyrosine kinase RET. Biochim Biophys Acta 2013; 1834(10): 2205-2212, http://dx.doi.org/10.1016/ j.bbapap.2012.10.008.

64. Takahashi M., Ritz J., Cooper G.M. Activation of a novel human transforming gene, ret, by DNA rearrangement. Cell 1985; 42(2): 581-588, http://dx.doi.org/10.1016/00928674(85)90115-1.

65. Iwamoto T., Taniguchi M., Asai N., Ohkusu K., Nakashima I., Takahashi M. cDNA cloning of mouse ret proto-oncogene and its sequence similarity to the cadherin superfamily. Oncogene 1993; 8(4): 1087-1091.

66. Schneider $R$. The human protooncogene ret: a communicative cadherin? Trends Biochem Sci 1992; 17(11): 468469, http://dx.doi.org/10.1016/0968-0004(92)90490-z.

67. Traugott A.L., Moley J.F. The RET protooncogene. Cancer Treat Res 2010; 153: 303-319, http://dx.doi.org/10.1007/978-14419-0857-5_17.

68. Anders J., Kjar S., Ibácez C.F. Molecular modeling of the extracellular domain of the RET receptor tyrosine kinase reveals multiple cadherin-like domains and a calcium-binding site. J Biol Chem 2001; 276(38): 35808-35817, http://dx.doi.org/10.1074/jbc. m104968200.

69. Nozaki C., Asai N., Murakami H., Iwashita T., Iwata Y., Horibe K., Klein R.D., Rosenthal A., Takahashi M. Calciumdependent Ret activation by GDNF and neurturin. Oncogene 1998; 16(3): 293-299, http://dx.doi.org/10.1038/sj.onc.1201548.

70. van Weering D.H., Bos J.L. Signal transduction by the receptor tyrosine kinase Ret. Recent Results Cancer Res 1998; 154: 271-281, http://dx.doi.org/10.1007/978-3-642-46870-4_18.
71. van Weering D.H., Moen T.C., Braakman I., Baas P.D., Bos J.L. Expression of the receptor tyrosine kinase Ret on the plasma membrane is dependent on calcium. $J$ Biol Chem 1998; 273(20): 12077-12081, http://dx.doi.org/10.1074/ jbc.273.20.12077.

72. Ibáñez C.F. Structure and physiology of the RET receptor tyrosine kinase. Cold Spring Harb Perspect Biol 2013; 5(2): a009134, http://dx.doi.org/10.1101/cshperspect.a009134.

73. Runeberg-Roos P., Saarma M. Neurotrophic factor receptor RET: structure, cell biology, and inherited diseases. Ann Med 2007; 39(8): 572-580, http://dx.doi.org/10.1080/0785389070 1646256

74. Liu X., Vega Q.C., Decker R.A., Pandey A., Worby C.A., Dixon J.E. Oncogenic RET receptors display different autophosphorylation sites and substrate binding specificities. J Biol Chem 1996; 271(10): 5309-5312, http://dx.doi.org/10.1074/ jbc.271.10.5309.

75. Kawamoto Y., Takeda K., Okuno Y., Yamakawa Y., Ito Y., Taguchi R., Kato M., Suzuki H., Takahashi M., Nakashima I. Identification of RET autophosphorylation sites by mass spectrometry. J Biol Chem 2004; 279(14): 14213-14224, http:// dx.doi.org/10.1074/jbc.m312600200.

76. Lemmon M.A., Schlessinger J. Cell signaling by receptor tyrosine kinases. Cell 2010; 141(7): 1117-1134, http://dx.doi. org/10.1016/j.cell.2010.06.011

77. Dhillon A.S., Hagan S., Rath O., Kolch W. MAP kinase signalling pathways in cancer. Oncogene 2007; 26(22): 32793290, http://dx.doi.org/10.1038/sj.onc.1210421.

78. Krishna M., Narang $\mathrm{H}$. The complexity of mitogen-activated protein kinases (MAPKs) made simple. Cell Mol Life Sci 2008; 65(22): 3525-3544, http://dx.doi.org/10.1007/s00018-008-8170-7.

79. Yang S.H., Sharrocks A.D., Whitmarsh A.J. MAP kinase signalling cascades and transcriptional regulation. Gene 2013; 513(1): 1-13, http://dx.doi.org/10.1016/j.gene.2012.10.033.

80. Raman M., Chen W., Cobb M.H. Differential regulation and properties of MAPKs. Oncogene 2007; 26(22): 3100-3112, http:// dx.doi.org/10.1038/sj.onc.1210392.

81. Turjanski A.G., Vaqué J.P., Gutkind J.S. MAP kinases and the control of nuclear events. Oncogene 2007; 26(22): 3240-3253, http://dx.doi.org/10.1038/sj.onc.1210415.

82. Reichardt L.F. Neurotrophin-regulated signalling pathways. Philos Trans R Soc Lond B Biol Sci 2006; 361(1473): 1545-1564, http://dx.doi.org/10.1098/rstb.2006.1894.

83. Ron D., Janak P.H. GDNF and addiction. Rev Neurosci 2005; 16(4): 277-285, http://dx.doi.org/10.1515/revneuro.2005.16.4.277.

84. Manning B.D., Cantley L.C. AKT/PKB signaling: navigating downstream. Cell 2007; 129(7): 1261-1274, http://dx.doi. org/10.1016/j.cell.2007.06.009.

85. Kim D., Chung J. Akt: versatile mediator of cell survival and beyond. J Biochem Mol Biol 2002; 35(1): 106-115, http://dx.doi. org/10.5483/bmbrep.2002.35.1.106.

86. Datta S.R., Brunet A., Greenberg M.E. Cellular survival: a play in three Akts. Genes Dev 1999; 13(22): 2905-2927, http:// dx.doi.org/10.1101/gad.13.22.2905.

87. Paratcha G., Ledda F., Ibácez C.F. The neural cell adhesion molecule NCAM is an alternative signaling receptor for GDNF family ligands. Cell 2003; 113(7): 867-879, http://dx.doi. org/10.1016/S0092-8674(03)00435-5.

88. Schmutzler B.S., Roy S., Pittman S.K., Meadows R.M., Hingtgen C.M. Ret-dependent and Ret-independent mechanisms of Gfl-induced sensitization. Mol Pain 2011; 7: 22, http://dx.doi. org/10.1186/1744-8069-7-22.

89. Gegelashvili G., Bock E., Schousboe A., Linnemann D. Two types of amyloid precursor protein (APP) mRNA in rat glioma cell lines: upregulation via a cyclic AMP-dependent pathway. 
Brain Res Mol Brain Res 1996; 37(1-2): 151-156, http://dx.doi. org/10.1016/0169-328x(95)00302-9.

90. Owczarek S., Kristiansen L.V., Hortsch M., Walmod P.S. Cell adhesion molecules of the NCAM family and their roles at synapses. The Sticky Synapse 2009; 265-299, http://dx.doi. org/10.1007/978-0-387-92708-4_13.

91. Ibáñez C.F. Beyond the cell surface: new mechanisms of receptor function. Biochem Biophys Res Commun 2010; 396(1): 24-27, http://dx.doi.org/10.1016/j.bbrc.2010.01.136.

92. Canty A.J., Dietze J., Harvey M., Enomoto H., Milbrandt J., Ibáñez C.F. Regionalized loss of parvalbumin interneurons in the cerebral cortex of mice with deficits in GFRalpha1 signaling. J Neurosci 2009; 29(34): 10695-10705, http://dx.doi.org/ 10.1523/JNEUROSCI.2658-09.2009.

93. Sjöstrand D., Ibácez C.F. Insights into GFRalpha1 regulation of neural cell adhesion molecule (NCAM) function from structure-function analysis of the NCAM/GFRalpha1 receptor complex. J Biol Chem 2008; 283(20): 13792-13898, http://dx.doi. org/10.1074/jbc.M800283200.

94. Yuste R. From the neuron doctrine to neural networks. Nat Rev Neurosci 2015; 16(8): 487-497, http://dx.doi.org/10.1038/ nrn3962.

95. Schlingloff D., Káli S., Freund T.F., Hájos N., Gulyás A.I. Mechanisms of sharp wave initiation and ripple generation. J Neurosci 2014; 20(34): 11385-11398, http://dx.doi. org/10.1523/JNEUROSCI.0867-14.2014.

96. Tong M.T., Peace S.T., Cleland T.A. Properties and mechanisms of olfactory learning and memory. Front Behav Neurosci 2014; 8: 238, http://dx.doi.org/10.3389/fnbeh.2014.00238.

97. Bourque M.J., Trudeau L.E. GDNF enhances the synaptic efficacy of dopaminergic neurons in culture. Eur $J$ Neurosci 2000; 12(9): 3172-3180, http://dx.doi.org/10.1046/j.14609568.2000.00219.x.

98. Nguyen Q.T., Parsadanian A.Sh., Snider W.D., Lichtman J.W. Hyperinnervation of neuromuscular junctions caused by GDNF overexpressionin muscle. Science 1998; 279: 1725-1729, http://dx.doi.org/10.1126/science.279.5357.1725.

99. Yang F., Feng L., Zheng F., Johnson S.W., Du J., Shen L., Wu C.P., Lu B. GDNF acutely modulates excitability and A-type $\mathrm{K}(+)$ channels in midbrain dopaminergic neurons. Nat Neurosci 2001; 4(11): 1071-1078, http://dx.doi.org/10.1038/nn734.

100. Wang C.Y., Yang F., He X.P., Je H.S., Zhou J.Z.,
Eckermann K., Kawamura D., Feng L., Shen L., Lu B. Regulation of neuromuscular synapse development by glial cell line-derived neurotrophic factor and neurturin. J Biol Chem 2002; 277(12): 10614-10625, http://dx.doi.org/10.1074/jbc.M106116200.

101. Wang J., Chen G., Lu B., Wu C.P. GDNF acutely potentiates $\mathrm{Ca}^{2+}$ channels and excitatory synaptic transmission in midbrain dopaminergic neurons. Neurosignals 2003; 12(2): 78-88, http://dx.doi.org/10.1159/000071817.

102. Weiss J.L., Burgoyne R.D. Sense and sensibility in the regulation of voltage-gated $\mathrm{Ca}^{2+}$ channels. Trends Neurosci 2002; 25(10): 489-491, http://dx.doi.org/10.1016/S0166-2236(02) 02247-6.

103. Ledda F., Paratcha G., Sandoval-Guzmán T., Ibáñez C.F. GDNF and GFRalpha1 promote formation of neuronal synapses by ligand-induced cell adhesion. Nat Neurosci 2007; 10(3): 293300, http://dx.doi.org/10.1038/nn1855.

104. Rutishauser U. Polysialic acid in the plasticity of the developing and adult vertebrate nervous system. Nat Rev Neurosci 2008; 9(1): 26-35, http://dx.doi.org/10.1038/nrn2285.

105. Võikar V., Rossi J., Rauvala H., Airaksinen M.S. Impaired behavioural flexibility and memory in mice lacking GDNF family receptor alpha2. Eur J Neurosci 2004; 20(1): 308-312, http:// dx.doi.org/10.1111/j.1460-9568.2004.03475.x.

106. Paratcha G., Ledda F. GDNF and GFRalpha: a versatile molecular complex for developing neurons. Trends Neurosci 2008; 31(8): 384-391, http://dx.doi.org/10.1016/j.tins.2008.05.003.

107. Choi D.W. Excitotoxic cell death. J Neurobiol 1992; 23(9): 1261-1276, http://dx.doi.org/10.1002/neu.480230915.

108. Lipton S.A., Rosenberg P.A. Excitatory amino acids as a final common pathway for neurologic disorders. $N$ Engl $J$ Med 1994; 330(9): 613-622, http://dx.doi.org/10.1056/ nejm199403033300907.

109. Vedunova M., Sakharnova T., Mitroshina E., Perminova M., Pimashkin A., Zakharov Yu., Dityatev A., Mukhina I. Seizure-like activity in hyaluronidase-treated dissociated hippocampal cultures. Front Cell Neurosci 2013; 7: 149, http:// dx.doi.org/10.3389/fncel.2013.00149.

110. Brené S., Messer C., Okado H., Hartley M., Heinemann S.F., Nestler E.J. Regulation of GluR2 promoter activity by neurotrophic factors via a neuron-restrictive silencer element. Eur J Neurosci 2000; 12(5): 1525-1533, http://dx.doi. org/10.1046/j.1460-9568.2000.00040.x. 